\title{
DONALD TRUMP'S USE OF TWITTER DURING HIS CAMPAIGN AHEAD OF THE US PRESIDENTIAL ELECTION OF 2016 - WHY TRUMP'S TWEETS ARE EMOTIONALLY EFFECTIVE
}

\author{
Mélanie Gantier \& Agnès Celle \\ Université Paris Diderot
}

\begin{abstract}
This paper shows how Donald Trump uses Twitter to spread emotions, more specifically fear and anger. Noteworthy is the fact that Trump's discourse is not primarily emotional. Although anger may sound legitimate, fear is viewed as an emotion one should be ashamed of. Rather than verbalising these emotions, discrediting his opponents - i.e. other candidates and journalists - and legitimising his own discourse for the sake of moral values are the hallmarks of Trump's rhetoric. By presenting the future as precarious and uncertain, he stands as the only one able to make America powerful and influential (again). He adopts the stance of a victim, which is amplified by the impact that social networks have on communities in terms of affiliation.
\end{abstract}

Pour Alicja en amical hommage

\section{INTRODUCTION}

In the Age of digital media and instantaneous communication, Donald Trump's choice to use Twitter as his favourite tool of communication comes as little surprise. This microblogging platform which can be described as "a form of blogging in which entries typically consist of short content such as phrases, quick comments, images, or links to videos" (Stieglitz, Dang-Xuan, 2013: 219, cited by Ott, 2017: 60), was launched in March 2006 and is now a major means 
of communication with over 500 million users. Moreover, it is a special and unique digital communication tool because there are no moderators to make sure some boundaries are not crossed, which therefore makes Twitter a platform of "free advertising for candidates" (Gross, Johnson, 2016: 748). Consequently, as repeatedly stressed by D. Trump in several interviews, Twitter allows him to reach out to millions of people: "I think I have a 125 million people between Twitter and Instagram and all of them and Facebook. I have a tremendous platform". Besides, it has been established that microblogging has a language of its own. In his review of Zappavigna (2012), Solmaz (2014: 412) argues that "political discourses on microblogging platforms support interpersonal bonding among the users". Discourse tagging through hashtags highlights key words or key themes, and this gathering around hashtags may generate a feeling of affiliation among members of a specific community. A case in point is the famous hashtag \#MakeAmericaGreatAgain that became a powerful slogan. \#DrainTheSwamp or \#CrookedHillary were also strong concise formulae aiming to destabilise and attack Trump's opponents. This interactional effectiveness is a key feature of the platform, as discourse on Twitter is reported to be simple, impulsive, and uncivil (Ott, 2017).

Another striking point that should be taken into account when dealing with D. Trump's use of Twitter is the fact that social media are now the main source of information in the United States. Indeed, "according to the Pew Research Center, $62 \%$ of U.S. adults get their news on social media" (Gottfried, Shearer, 2016, cited in Ott, ibid., p. 65). This percentage may raise some questions about the accuracy and even the truth of the information massively shared and spread, as Twitter users do not have the possibility to check information sources and therefore may fuel calumny in instantaneous retweets. Besides, D. Trump's stylistic practices such as his use of an exclamatory punctuation "reinforce the negative sentiment of his Tweets and heighten their emotional impact, which, in turn, is reflected in the intense emotion of his followers, a phenomenon scholars refer to as «emotional contagion»" (Auflick, 2016, cited in Ott, ibid., p. 64).

The nature of this emotional contagion through discourse is worth investigating. It is argued that fear and anger are likely to be induced in the recipients of Trump's tweets although these emotions are not conveyed as such in Trump's tweets. Furthermore, we aim to show that D. Trump's use of language and his manipulative use of Twitter are telltale signs of propaganda. The time frame for this study spans the period from June $16^{\text {th }} 2015$, when Donald Trump officially

${ }^{1}$ Full transcript of Donald Trump interview with Maria Bartiromo: http://www.valuewalk. com/2017/10/trump-bartiromo/?all=1 (accessed 19.01.2018). 
announced his candidacy for President on Twitter, to November $8^{\text {th }} 2016$, when he became the $45^{\text {th }}$ president of the United States. The corpus is made up of 5109 tweets and more precisely of 127109 characters including words and punctuation marks. The textometric software tool TXM (Heiden, 2010 and Heiden, Magué, Pincemin, 2010) was used to uncover discourse patterns through the search for key words and strong punctuation marks.

\section{The Defining Features OF TRUMP'S RHETORIC}

Paradoxically, Trump's discourse appears to be prone to spread emotions without lexically mentioning those emotions. Emotions can be either described or expressed (see Celle et al., 2017). However, fear and anger are neither described nor expressed in D. Trump's online discourse. Indeed, out of 5109 tweets, there are no occurrences of the psychological verbs to frighten and to scare. The verb to fear and the psychological noun fear are only used once each, whereas anger is used four times, as in the following tweet:

(1) Many people are now saying I won South Carolina because of the last debate. I showed anger and the people of our country are very angry! (2016.02.22)

Anger is generally defined as the manifestation of a deep emotional outburst and has been negatively perceived since antiquity. Galen and Seneca analysed it as some form of madness, while in Catholicism, anger is one of the seven capital sins (Pierens, 2014: 78). However, according to Aristotle, anger may be morally justified: "l'homme qui se met en colère pour des motifs valables et contre qui le mérite, ajoutons encore au moment et durant le temps voulus, obtient notre approbation" (Aristote, Éthique à Nicomaque, IV, 11, cited by Pierens, ibid.). Therefore, anger is a very ambiguous feeling. Although it is provoked by something negative, it may be claimed to be legitimate, as is the case in D. Trump's tweet. Indeed, in (1) Trump explicitly expresses his emotion and does not attempt to hide it. His rage is a response to a feeling of injustice and therefore this feeling of injustice can also rationalise and legitimate his rage (Miller, 2001). By contrast, fear appears to be an undesirable emotion that is negatively perceived, and fear is always attributed to somebody else, especially to Trump's opponents, as in the following tweet:

(2) Just watched recap of \#CrookedHillary's speech. Very short and lies. She is the only one fear-mongering! (2016.08.25) 
Indeed, the target of this tweet, H. Clinton, is placed in a position of weakness because she is designated as the one who provoked a feeling of fear among the voters. Generally speaking, the expression Crooked Hillary is used 202 times in our corpus of tweets. The insulting attributive adjective crooked spreads calumny against her, which may then induce not only anger but also a loss of trust among the voters, who may question her skills and her ability to lead the country. For example, $\mathrm{H}$. Clinton is attacked on several issues in an attempt to make her appear weak in both her foreign and internal policy choices:

\section{(3) CLINTON'S FLAILING SYRIA POLICY WAS JUDGED A FAILURE.} (2016.10.05)

(4) Hillary is too weak to lead on border security-no solutions, no ideas, no credibility. She supported NAFTA, worst deal in US history. \#Debate. (2016.10.20)

She is also attacked on the decisions that were made by her husband B. Clinton, and is thereby associated with the doings of a former president:

(5) Our country is stagnant. We've lost jobs and business. We don't make things anymore $b / c$ of the bill Hillary's husband signed and she blessed. (2016.10.20)

The conjunction because is a key word in D. Trump's discourse. Although he does not describe emotions such as anger and fear and rarely expresses them, he intends to inspire them. By using because, he is pointing his finger at the cause of America's economic recession, which provides the source of his recipients' anger and fear. H. Clinton is held responsible for the US's economic situation and loss of jobs in general. Furthermore, he sneaks in the idea that his opponents are corrupt and unfit to lead a country, and by contrast presents himself as the only one fitting for the job. For example, with his tweet "We need a real President", he suggests that he would be the only real President, whereas H. Clinton would not be a good one, should she be elected. This strategy is the same as the one adopted against the media, with the intention to provoke distrust against traditional journalism, as opposed to his "own form of media", supposedly the only real and trustworthy one. In sum, value reversal is a key element of Trump's rhetoric so as to provoke fear and anger against his designated enemies. In addition, because fear is not a legitimate emotion but rather an emotion to be ashamed of, he insidiously induces it, especially through references to terror attacks: 
(6) Incompetent Hillary despite the horrible attack in Brussels today wants borders to be weak and open-and let the Muslims flow in. No way! (2016.03.23)

In (6), Trump is referring to the terror attack in Brussels on March 22, 2016, in which 32 people were killed. Strikingly, this example epitomises all the features of Trump's rhetorical strategy. Firstly, his opponent H. Clinton is explicitly attacked through the insulting attributive adjective incompetent. Her skills are questioned in order to induce a feeling of distrust. Secondly, fear is triggered by the reference to terror attacks and by the claim that $\mathrm{H}$. Clinton wants to open borders. He is implying that the same attack could occur in the US because of her alleged incompetence and her poor political choices. Finally, he explicitly targets "Muslims", a community that would be flowing into the country should Hillary Clinton be elected. The fact that he names a specific threat is correlated with his intention to elicit irrational fear. As stated by Crépon (2008: 17), "La culture de la peur [...] est indissociable d'une redoutable culture de l'ennemi". This enemy may well not exist as such. As demonstrated by Bauman \& Bury (2007), the "culture of fear" is intertwined with the concept of "surrogate targets" that is to say, categories of individuals (foreigners, immigrants, etc.) on which people can vent their frustrations and their fear. The slurred person or group is degraded and dehumanised. As a result, some emotions, such as anger and fear, are exacerbated, at the expense of others, such as empathy.

The use of metaphors contributes to distorting the perception of reality. The use of flow in is interesting, as it belongs in the semantic field of submersion and flooding, as if the US had become an endangered place. In the same way, in the following tweet the verb swamp is used metaphorically to raise concern about disorder and dishonesty in the public sphere:

(7) If I win the Presidency we will swamp Justice Ginsburg with real judges and real legal opinions. (2016.07.13)

The verbs flow in and swamp are linked to the two emotions under study: in (6), the verb conveys the fear of drowning and being flooded, whereas in (7), water is metaphorically referred to to express vengeful anger against a judge of the Supreme Court, who is accused of being fake and of not serving the people correctly. Indeed, the adjective real is repeated twice and is generally a key word in Trump's discourse. He claims to be the possessor of truth, integrity and justice whereas his opponents are reported to be wrong, fake and dishonest. Crucially,

\footnotetext{
${ }^{2}$ Our translation of "cibles de substitution” from Bauman \& Bury (2007).
} 
Trump's tweets promote the values of democracy, only to diminish them. Calumny and the distortion of reality serve to undermine the foundations of democracy. Through this "undermining propaganda" (Stanley, 2015: 54) ${ }^{3}$, he appears as a saviour and as the only option for a country facing a gloomy and uncertain future.

The future is a key issue in Trump's discourse. As a matter of fact, the future is related to epistemicity. The epistemic attitude of a speaker and the way they conceive of the future is influenced by their emotional state. Trump frequently refers to the future using the modal auxiliary will $(\mathrm{n}=813)$, which signals his absolute certainty and his control over future events. This is especially clear in first-person utterances:

(8) I will rebuild the military take care of vets and make the world respect the US again! (2015.09.15)

(9) [...] We will Make America Great Again! (2015.07.22)

This way of referring to the future is indicative of a strong commitment on the part of the speaker and is in keeping with the Republican tradition observed by Bendinelli (2012: 371). However, what makes D. Trump's tweets different is the way he creates a sense of uncertainty about the future using the modal will. In negated third-person utterances, the speaker commits to the subject's failure:

(10) [...] Bush will NEVER Make America Great Again! (2015.06.25)

(11) Jeb Bush will never secure our border or negotiate great trade deals for American workers. [...] (2015.07.05)

In contrast to Trump, other candidates are presented as bound to fail. This derogatory claim about his opponents creates a sense of uncertainty about the future, should anyone but him be elected. Such an epistemic state has emotional implications. As pointed out by Tiedens \& Linton (2001: 974), "the emotions of hope, surprise, fear, worry, and, to some extent, sadness, are associated with the

${ }^{3}$ Stanley (2015: 48) defines propaganda as a "manipulation of the rational will to close off debate". This is achieved through the use of emotion, deception and stereotype. Noteworthy is the fact that emotions are "detached from their ideas". Stanley further differentiates between "supporting propaganda" (p. 53), which supports totalitarian regimes, and "undermining propaganda" (p. 54), which erodes democracies by appealing to democratic values while at the same time undermining them. 
sense of uncertainty (Roseman, 1984; Scherer, 1984; Smith \& Ellsworth, 1985)". Trump's reference to a looming future may instil a sense of uncertainty and concern in American citizens.

The topic of employment and unemployment turns out to be a crucial one, producing what Plantin (2012) calls a "situation émotionnante", i.e. a situation that triggers emotions and especially a sense of threat:

(12) Mexican leaders and negotiators are much tougher and smarter than those of the U.S. Mexico is killing us on jobs and trade. WAKE UP! (2015.07.03)

In this tweet, Mexico is designated as the enemy stealing jobs from the American workers. D. Trump is tracing the cause of unemployment and the neighbouring country is found guilty, which backs up the idea that anger is an agent-related emotion (Dijk, Zeelenberg, 2002). Finally, the Republican candidate plays with the nostalgia of the voters and their fear that the US will no longer be the powerful and successful country it used to be:

(13) It was great being in Michigan. Remember I am the only presidential candidate who will bring jobs back to the U.S. and protect car industry! (2016.03.07)

The use of the phrasal verb bring back suggests that the Americans were better off in the past. American citizens may feel downgraded in terms of international clout, so D. Trump may appear to be the only option, through his self-appointed role as a protector and a saviour who will restore the former fantasied glory of the country. The use of imperatives in directive utterances (wake up! in capital letters in (12), remember in (13)) is a direct form of address that creates a sense of urgency. The addressee has to react - and to vote accordingly - in order to avoid the looming catastrophe.

\section{AN UNPRECEDENTED SOCIAL MEDIA COVERAGE WITH A POWERFUL EMOTIONAL IMPACT}

First of all, the circumstances of the last American presidential election are particularly interesting, as it was the first time social media and especially Twitter had been used to such an extent by a candidate, with an unexpected but successful outcome since D. Trump became President of the United States. In an interview with Fox News, on March $15^{\text {th }} 2017$, he said: 
(14) I think that maybe I wouldn't be here if it wasn't for Twitter, because I get such a fake press, such a dishonest press [.... I have my own form of media. (2017.03.15)

He thus presents his Twitter account as the only honest and reliable source of information, as opposed to traditional journalism which he often blames in an insulting way for propagating fake news ${ }^{4}$ :

(15) The press is so totally biased that we have no choice but to take our tough but fair and smart message directly to the people! (2016.06.15)

D. Trump is twisting facts, not only by discrediting classic media, which are depicted as "dishonest", "biased", "corrupt" and "distorted", but also by assuring the only information to be trusted is the one he distributed himself through social media. Passing himself off as a victim of fake news, he intends to control information by discrediting any news that does not come from him, and by legitimating his own words.

As pointed out by Justin H. Gross and Kaylee T. Johnson (2016: 749), tweets may be used by a candidate to explicitly attack another candidate. Gross and Johnson (2016) aim to measure the impact of "going negative" both in polls and in the Republican campaign. This expression means "attacking opponents based on their personal traits, issue positions, or the political party to which they belong (Surlin and Gordon, 1977; Skaperdas and Grofman, 1995)" (Gross, Johnson, ibid., p. 748). In other words, they intend to find out to what extent negative tweets are likely to influence polls and voters in favour of the author of such attacks. Unsurprisingly, their findings revealed that Donald Trump dominated the field as both author and target of negative tweets during the campaign, while opinion polls simultaneously showed that he was the favourite candidate. A correlation between those two findings was established. Negative tweets are likely to elicit long-term negative emotions, such as anger and fear. As demonstrated by Hill et al. (2010), emotions spread like infectious diseases on social networks.

Furthermore, freedom of speech combined with the right to react to "fake media" is advocated in Donald Trump's claim that social media give him a chance to counterattack:

${ }^{4}$ See also: The 424 People, Places and Things Donald Trump has insulted on Twitter: A Complete List, The New York Times, https://www.nytimes.com/interactive/2016/01/28/upshot/ donald-trump-twitter-insults.html (accessed 15.01.2018). 
(16) And I doubt I would be here if it weren't for social media, to be honest with you. Because there is a fake media out there, I get treated very unfairly by the media. [...] When somebody says something about me, I am able to go 'bing, bing, bing' and I take care of it $^{5}$. (2017.10.20)

This ability to "go «bing, bing, bing»" and to "take care of it" is coherent with Ott's conclusion that Trump's tweets are mostly negative and aiming to attack his opponents: "Trump's simple, impulsive, and uncivil Tweets do more than merely reflect sexism, racism, homophobia, and xenophobia; they spread those ideologies like a social cancer. [...] His tweets teach us to see others as less-than-human and they inspire hatred and violence" (Ott, op. cit., p. 64). Besides, Donald Trump has the most negative audience, just like BBC Breaking News and CNN Breaking News (Bae, Lee, 2012).

The creation of new phrases such as "go bing bing", in which an onomatopoeic word is used in a go-construction is typical of Trump's attempt to adopt a supposedly natural style of speaking. In this respect, his style and Twitter's underlying logic are "wholly homologous" (Ott, ibid., p. 63), since his style is mainly based on monosyllabic words that are meant to capture reality in a direct way, in the same way as Twitter gives him a chance to act as a provider of unmediated information. However, this apparent simplicity is based on evaluative judgments. The onomatopoeic word bing is used in place of an adjective in a go-construction that typically conveys evaluative modality (Bourdin, 2003). Evaluative qualitative adjectives such as great, bad or sad are among the most commonly used in Trump's discourse with respectively 557, 151 and 62 occurrences, whereas classifying adjectives and epistemic adjectives are scarcely used. The classifying adjective democratic occurs 11 times and the epistemic adjectives likely and unlikely occur only once each. Evaluative adjectives express moral judgment and potentially moral blame. Moral judgments may partly account for the highly emotional impact of Trump's tweets, although his tweets are not primarily emotional.

\section{Conclusion}

We argued that D. Trump never explicitly expresses fear, this emotion being a shameful one. By contrast, anger is morally legitimate because it is viewed as a sound response to some injustice inflicted upon the American people, which D. Trump seeks to remedy in order to restore national confidence. Nonetheless,

${ }^{5}$ Full transcript of Donald Trump's interview with Maria Bartiromo: http://www.valuewalk. com/2017/10/trump-bartiromo/?all=1 (accessed 19.01.2018). 
anger is seldom expressed as such. Indeed, the Republican candidate chose to provoke and trigger these emotions in his recipients rather than explicitly express them. In order to do so, he presented himself as the only honest and competent candidate and as the only reliable source of information, as opposed to the supposedly fake media. Therefore, his opponents, i.e. both journalists and the other candidates, were insulted and disqualified, while D. Trump cast himself as a protector invested with a mission to save the country and its citizens:

(17) Together we can save American JOBS American LIVES and AMERICAN FUTURES! \#Debates. (2016.10.20)

By adopting a stance as defender of moral values, Trump had a high emotional impact, even if his discourse was not emotional per se. This impact was amplified by the social media which allowed those emotions to go viral and spread. In addition, social media bring speaker and recipients closer and create affective affiliation.

\section{Bibliographical references}

AUFLICK, Thomas (2016), How Trump's high level of emotion attracts and repels followers simultaneously, www.linkedin.com/pulse/how-trumps-high-level-emotion-attracts-repels-aufli ck-ma-lmhca (accessed 18.01.2018).

BAE, Younggue, LEE, Hongchul (2012), « Sentiment analysis of twitter audiences: Measuring the positive or negative influence of popular twitterers », Journal of the American Society for Information Science and Technology, vol. 63, n 12, pp. 2521-2535.

BAUMAN, Zygmunt, BURY, Laurent (2007), Le présent liquide, Paris, Seuil.

BENDINELLI, Marion (2012), Étude des auxiliaires modaux et des semi-modaux dans les débats présidentiels américains (1960-2008) : analyse qualitative et quantitative, Thèse de doctorat, Université de Nice Sophia Antipolis.

BOURDIN, Philippe (2003), « On two distinct uses of go as a conjoined marker of evaluative modality », in Modality in contemporary English (R. Facchinetti, M. Krug, F. Palmer éds), Berlin/New York, Mouton de Gruyter, pp. 103-127.

CELLE, Agnès, JUGNET, Anne, LANSARI, Laure, L'HÔTE, Emilie (2017), « Expressing and Describing Surprise ", in Expressing and Describing Surprise (A. Celle, L. Lansari éds), Amsterdam, John Benjamins, pp. 215-244.

CRÉPON, Marc (2008), La culture de la peur, Paris, Galilée.

DIJK, Wilco W. van, ZEELENBERG, Marcel (2002), " Investigating the Appraisal Patterns of Regret and Disappointment », Motivation and Emotion, vol. 26, n 4, pp. 321-331.

GOTTFRIED, Jeffrey, SHEARER, Elisa (2016), « News Use Across Social Media Platforms », Pew Research Center, www.journalism.org/2016/05/26/news-use-across-social-media-platforms-2016 (accessed 20.01.2018). 
GROSS, Justin H., JOHNSON, Kaylee T. (2016), « Twitter Taunts and Tirades: Negative Campaigning in the Age of Trump », PS: Political Science \& Politics, vol. 49, no 4, pp. 748-754.

HEIDEN, Serge (2010), « The TXM Platform: Building Open-Source Textual Analysis Software Compatible with the TEI Encoding Scheme ", in 24 ${ }^{\text {th }}$ Pacific Asia Conference on Language, Information and Computation (R. Otoguro et al. éds), Sendai, Waseda University.

HEIDEN, Serge, MAGUÉ, Jean-Philippe, PINCEMIN, Bénédicte (2010), « TXM: Une plateforme logicielle open-source pour la textométrie - conception et développement $»$, in $10^{\text {th }}$ International Conference on the Statistical Analysis of Textual Data-JADT 2010 (S. Bolasco, I. Chiari, L. Giuliano éds), vol. 2 (3), Roma, Edizioni Universitarie di Lettere Economia Diritto, pp. 1021-1032.

HILL, Alison L., RAND, David G., NOWAK, Martin A., CHRISTAKIS, Nicholas A. (2010), « Emotions as infectious diseases in a large social network: the SISa model », Proceedings for the Royal Society B, www.rspb.royalsocietypublishing.org/content/277/1701/3827 (accessed 16.01.2018).

MILLER, Dale T. (2001), " Disrespect and the Experience of Injustice », Annual Review of Psychology, vol. 52, n 1 , pp. 527-553.

OTT, Brian L. (2017), " The age of Twitter: Donald J. Trump and the politics of debasement », Critical Studies in Media Communication, vol. 34, $\mathrm{n}^{\circ}$ 1, pp. 59-68.

PIERENS, Matthieu (2014), Les sentiments négatifs à travers les siècles : l'évolution des champs sémantiques de la colère, de la peur et de la douleur en français dans la base textuelle FRANTEXT (1500-2000), Thèse de doctorat, Université Paris Diderot.

PLANTIN, Christian (2012), «Les séquences discursives émotionnées : Définition et application à des données tirées de la base CLAPI » in SHS Web of Conferences. $3^{e}$ Congrès Mondial de Linguistique Française (F. Neveu et al. éds), vol. 1, Lyon, EDP Sciences, pp. 629-642, www.shs-conferences. org/articles/shsconf/pdf/2012/01/shsconf_cmlf12_000218.pdf(accessed 14.01.2018).

ROSEMAN, Ira J. (1984), « Cognitive determinants of emotion: A structural theory », Review of Personality and Social Psychology, ${ }^{\circ}$ 5, pp. 11-36.

SCHERER, Klaus R. (1984), " On the nature and function of emotion: A component process approach », in Approaches to emotion (K. R. Scherer, P. Ekman éds), pp. 293-317, Hillsdale, NJ, Erlbaum.

SKAPERDAS, Stergios, GROFMAN, Bernard (1995), " Modeling Negative Campaigning », The American Political Science Review, vol. 89, $\mathrm{n}^{\circ}$ 1, pp. 49-61.

SMITH, Craig A., ELLSWORTH, Phoebe C. (1985), « Patterns of cognitive appraisal in emotion », Journal of Personality and Social Psychology, $\mathrm{n}^{\circ} 48$, pp. 813-838.

SOLMAZ, Osman (2014), Book Review of « Discourse of Twitter and Social Media: How We Use Language to Create Affiliation on the Web », M. Zappavigna (éd.), 2012, CALICO Journal, vol. 31, n 3 , pp. 412-414.

STANLEY, Jason (2015), How propaganda works, Princeton, Princeton University Press.

STIEGLITZ, Stefan, DANG-XUAN, Linh (2013), « Emotions and Information Diffusion in Social Media - Sentiment of Microblogs and Sharing Behavior », Journal of Management Information Systems, vol. 29, pp. 217-248.

SURLIN, Stuart H., GORDON, Thomas F. (1977), « How Values Affect Attitudes toward Direct Reference Political Advertising », Journalism \& Mass Communication Quarterly, vol. 54, $\mathrm{n}^{\circ} 1$, pp. 89-98. 
TIEDENS, Larissa Z., LINTON, Susan (2001), « Judgment under emotional certainty and uncertainty: the effects of specific emotions on information processing », Journal of Personality and Social Psychology, vol. 81, $\mathrm{n}^{\circ}$ 6, pp. 973-988.

ZAPPAVIGNA, Michele (2012), Discourse of Twitter and Social Media: How We Use Language to Create Affiliation on the Web, New York, Continuum.

\section{Corpus}

www.trumptwitterarchive.com/archive (accessed 04.12.2017).

\section{Sitography}

www.valuewalk.com/2017/10/trump-bartiromo/?all=1.

www.nytimes.com/interactive/2016/01/28/upshot/donald-trump-twitter-insults.html. 